\title{
Expressions of CYP and GST Isoenzymes in Human Gastric Tumor and Non-Tumor Tissues
}

\author{
Gulcin G. SIMSEK ${ }^{1}$, Serpil OGUZTUZUN² ${ }^{2}$ Busra BOZER ${ }^{4}$, Murat KILIC 3 , \\ Arzu K. KOCDOGAN 5 , Pinar KAYGIN², Nurdan GURBUZ2, Hakan BULUS ${ }^{6}$ \\ ${ }^{1}$ University of Health Sciences, Kecioren Training and Research Hospital, Department of Pathology, Ankara \\ ${ }^{2}$ Kirikkale University, Faculty of Arts and Sciences, Department of Biology, Kirikkale \\ ${ }^{3}$ Ankara University Vocational School of Health Services Department of Pharmacy, Ankara \\ ${ }^{4}$ Hitit University, Scientific Technical Research and Application Center, Corum \\ ${ }^{5}$ Gelisim University, Health Services Vocational High School Pathology Laboratory Techniques Department, İstanbul \\ ${ }^{6}$ University of Health Sciences, Kecioren Training and Research Hospital, \\ Department of General Surgery, Ankara, TURKEY
}

\begin{abstract}
In this study we investigated the immunohistochemical staining characteristics of cytochrome P450 1A1 (CYP1A1), CYPB1, CYP2E1 and glutathione S-transferase P1 (GSTP1), GSTT1, GSTO1, GSTK1 isoenzymes in gastric tumor and surrounding tumor free (normal) gastric tissues from 40 patients. For immunohistochemical studies, tissues were obtained from 40 patients with gastric adenocarcinoma. Tumor and non-tumoral control tissues of patients were compared according to their staining intensity. Relationships between CYP and GST isoenzyme expressions in adenocarcinoma tissues were examined by the Mann Whitney- $U$ test, and the clinicopathological data were examined by the Spearman's Rank Correlation test. CYP1B1, GST1, GSTO1 and GSTK1 expressions in gastric cancer cells were significantly higher than those in gastric normal epithelial cells $(p<0.05)$. However, CYP1A1, CYP2E1 and GSTP1 expressions were not significantly higher in tumor epithelium than those in normal epithelium in human gastric adenocancer $(p<0.05)$. Among the studied CYPs and GSTs, there was not statistically significant association between the studied isoenzyme expressions and age, gender and tumor grade ( $p>0.05$ ). In patients with gastric adenocarcinoma, CYP1B1, GSTO1, GSTT1, and GSTK1 protein expressions are higher in tumor than normal gastric tissues.
\end{abstract}

Keywords: Gastric adenocarcinoma, Cytochrome P450 enzymes, Glutathione-S-transferase

ÖZET

İnsan Gastrik Tümörü ve Tümör Olmayan Dokulardaki CYP ve GST İzozimlerinin Ekspresyonları

Bu çalışmada, 40 gastrik kanser hastasında, tümörlü ve tümör periferinde bulunan normal dokularında sitokrom P450 1A1 (CYP1A1), CYPB1, CYP2E1 ve glutatyon S-transferaz P1 (GSTP1), GSTT1, GSTO1, GSTK1 izozimlerinin immünohis`tokimyasal boyanma Özellikleri araştııımıştır. Immünohistokimyasal çalışmalar için dokular, gastrik adenokarsinomalı 40 hastadan elde edildi. Hastaların tümör ve normal kontrol dokuları boyama yoğunluğuna göre karşılaştııldı. Adenokarsinoma dokularında CYP ve GST izoenzimlerinin ekspresyonları arasındaki ilişki Mann Whitney-U testi ile ve klinikopatolojik veriler Spearman korelasyon rank testi ile incelendi. Gastrik kanserli dokularda CYP1B1, GST1, GSTO1 ve GSTK1 ekspresyonlarının normal dokulara oranla daha fazla olduğu istatistiksel olarak anlamlı bulundu ( $\mathrm{p}<$ 0.05). Fakat, CYP1A1, CYP2E1 ve GSTP1 ekspresyonlarının normal dokulara oranla daha az olduğu istatistiksel olarak anlamlı bulundu $(p<0.05)$. Çalıșlan CYP ve GST izozimlerinin ekspresyonları ile yaș ve cinsiyet arasında istatistiksel olarak anlamlı bir ilişki bulunamadı ( $p>0.05)$. Gastrik adenokarsinomalı hastalarda, CYP1B1, GSTO1, GST1 ve GSTK1 protein ekspresyonları tümörlü dokuda, normal gastrik dokulardan daha yüksektir.

Anahtar Kelimeler: Gastrik adenokarsinoma, Sitokrom P450 enzimleri, Glutatyon-S-transferaz 


\section{INTRODUCTION}

Gastric cancer is one of the most common malignancies in the world. Nutritional, infectious and genetic factors have been shown to play a role in multistage process of gastric carcinogenesis. ${ }^{1-3}$ Also, several lines of evidence have indicated that cigarette smoking is a risk factor for developing gastric cancer ${ }^{4,5}$ and that the carcinogens in tobacco smoke, such as benzo[ $\alpha]$ pyrene ${ }^{6}$ and in drinking water ${ }^{7}$ are involved in gastric carcinogenesis. Many potentially carcinogenic compounds first require metabolic activation by phase I enzymes and then are subjected to detoxification by phase II enzymes.

Phase I enzymes are encoded by the cytochrome P450 (CYP450s) gene family, and phase II enzymes include the glutathione-S-transferases (GSTs). The glutathione S-transferase (GST) family of genes has a critical function in protection against electrophiles and the products of oxidative stress. ${ }^{8,9}$ GSTs are involved in the metabolism of many xenobiotics, including an array of environmental carcinogens, chemotherapeutic agents and endogenously derived reactive oxygen species. 8 GSTs have classified into at least eight genetically distinct classes: alpha, mu, pi, theta, omega, kappa, zeta and sigma. ${ }^{10}$

Chen et al. found that GSTT1 null genotype was associated with a statistically significant increased risk of gastric cancer. They also showed that the frequency of GSTT1 null genotype was distinctly different between Asians and Caucasians. ${ }^{11}$

González et al. found no significant differences in GSTP1 Ile105Val (rs1695) and GSTP1 Val114Ala (rs1138272) genotype distribution were observed between gastric cancer patients and control. ${ }^{12}$

In this study, we aimed to investigate the expression of GSTT1, GSTP1, GSTO1,GSTK1 and CYP1A1, CYP1B1, CYP2E1 isoenzymes in gastric adenocarcinoma patients.

\section{PATIENTS AND METHODS}

\section{Patients}

Gastric adenocarcinoma and normal (surrounding tumor-free) tissue samples were obtained from 40 patients, 29 male and 11 female (mean age

\begin{tabular}{|c|c|c|}
\hline & $\mathbf{n}$ & $\%$ \\
\hline GastricAdenocancer & 40 & 100 \\
\hline \multicolumn{3}{|l|}{ Gender } \\
\hline Male & 29 & 72.5 \\
\hline Female & 11 & 27.5 \\
\hline Mean & \multicolumn{2}{|c|}{ Mean $(64,4) ;$ Range $(45-90)$} \\
\hline$<68$ & 23 & 57.5 \\
\hline$>68$ & 17 & 42.5 \\
\hline \multicolumn{3}{|l|}{ Tumor differentiation } \\
\hline G1 & 13 & 32.5 \\
\hline G2 & 14 & 35 \\
\hline G3 & 13 & 32.5 \\
\hline
\end{tabular}

64.4 \pm 13.024) (Table 1), who were diagnosed at Health Sciences University Kecioren Training and Research Hospital, Ankara, Turkey, between 2009 and 2012. The samples were stained immunohistochemically with the antibodies. For all patients, questionnaires including information about age, gender, and smoking status were obtained. Operation material was examined macroscopically by two pathologists in each case. Tissues were fixed overnight. Two sections were taken from the patient: one from the tumor tissue and one from normal tissues adjacent to the tumor used as controls. Due to heterogeneity of the histological subtypes, gastric adenocarcinoma subtyping wasn't performed in the microscopical examination of the study. Grading of the tumor were not included to the study.

\section{Immunohistochemical Staining}

The tissues were fixed in $10 \%$ buffered formalin and embedded in paraffin blocks. Sections were cut $4 \mu \mathrm{m}$ thick, and one section was stained with hematoxylin and eosin to observe the tissue morphology and tumor score. For immunohistochemistry, endogenous peroxidase activity was blocked by incubating the sections in $1 \%$ hydrogen peroxide $(\mathrm{v} / \mathrm{v})$ in methanol for 10 minutes at room tempera- 
International Journal of Hematology and Oncology

Table 2. The number and percentages of patients with higher CYPs expressions in tumor tissues than normal tissues

\begin{tabular}{|llllllll|}
\hline & & \multicolumn{2}{c}{ CYP1A1 } & \multicolumn{2}{c}{ CYP1B1 } & \multicolumn{2}{c|}{ CYP2E1 } \\
\cline { 3 - 8 } & Total $(\mathbf{n})$ & Tumor $(\mathbf{n})$ & $\%$ & Tumor $(\mathbf{n})$ & $\%$ & Tumor $(\mathbf{n})$ & $\%$ \\
\hline \multirow{2}{*}{ Gastric Cancer } & 40 & 10 & 25 & 24 & 60 & 11 & 27.5 \\
\hline
\end{tabular}

ture (RT). The sections were subsequently washed in distilled water for 5 minutes, and antigen retrieval was performed for 3 minutes using $0.01 \mathrm{M}$ citrate buffer ( $\mathrm{pH}$ 6.0) in a domestic pressure cooker. After washing in water, the sections were transferred in $0.05 \mathrm{M}$ Tris- $\mathrm{HCl}(\mathrm{pH} 7.6)$ containing $0.15 \mathrm{M}$ sodium chloride tris buffered saline (TBS). Then, the sections were incubated at RT for 10 minutes with super block (SHP125) (ScyTek Laboratories, USA) to block nonspecific background staining. The sections were then covered with the primary antibodies diluted 1:250 for anti-GSTP1, 1:400 for anti-GSTK1, 1:500 for anti-GSTT1, 1:250 for anti-GSTO1, 1:50 for anti-CYP1A1, 1: 400 for anti-CYP1B1, 1:250 for anti-CYP2E1 in TBS at 4oC overnight. (Anti-GSTK1 (EPR1939) was from Origene Technologies Inc., USA; GSTO1 (ab88604) was from Abcam Inc., USA; AntiCYP1A1 (sc-20772) and Anti-GSTP1 (sc-28494) were from Santa Cruz Biotechnology Inc., USA; Anti-CYP1B1 (sc-32882) was from Santa Cruz Biotechnology Inc., USA; Anti-CYP2E1 (PA1116) was from BOSTER Biological Technology., Ltd. USA). After washing in TBS for 15 minutes, the sections were incubated at RT for biotinylated link antibody (SHP125) (ScyTek Laboratories, USA). Then, treatment was followed with Streptavidin/ HRP complex (SHP125) (ScyTek Laboratories, USA). Diaminobenzidine was used to visualize peroxidase activity in the tissues. Nuclei were lightly counterstained with haemotoxyline, and then the sections were dehydrated and mounted. Both positive and negative controls were included in each run. Positive controls consisted of sections of gallbladder tissues for CYP1A1 and skeletal muscle tissues for CYP1B1, liver tissues for GSTK1 and GSTP1, lung tissues for GSTT1, CYP2E1, colon tissues for GSTO1. TBS was used in place of the primary antibody for negative controls.
Light microscopical examination of immunohistochemically stained sections was performed by a pathologist and a biologist, who had no knowledge of the patients' clinical information. Distribution, localization and characteristics of immunostaining were recorded. Brown color in cytoplasm of epithelial cells was evaluated as positive staining. Scoring was also performed by pathologist unaware of the patient data. Scoring differences between pathologists were resolved by consensus. For each antibody, the intensity of the reaction; negative $(-)$, weak $(1+)$, moderate $(2+)$ or strong (3+) was determined in order to describe the immunoreactions.

\section{Statistical Analysis}

In the study, MINITAB 14 statistical software (MINITAB release 14.12.0, MINITAB INC. State Collage, Pennsylvania, United States) was used for statistical evaluations. Expressional differences of CYP and GST isoenzyms between tumor and normal tissues were examined by Mann-Whitney U Test and relationships between CYP and GST proteins expressions and clinical data of patients (such as age, gender, smoking status, tumor grade) were examined by the Spearman's Rank Correlation Test. The results were found to be significant for $\mathrm{p}<0.05$.

\section{RESULTS}

Fourty paired samples of gastric adenocarcinoma and the surrounding normal gastric tissue were examined from 40 patients.

We found normal gastric mucosa to be characterized by a low frequency of expression of CYP1A1, CYP1B1, CYP2E1, GSTP1, GSTT1, GSTO1 and GSTK1. In contrast, gastric carcinoma cells were found to exhibit a very high frequency of expression of all the studied CYP and GST proteins with respect to normal gastric mucosa (Table 2, 3). 
International Journal of Hematology and Oncology

Table 3. The number and percentages of patients with higher GSTs expressions in tumor tissues than normal tissues

\begin{tabular}{|lllllllllll|}
\hline & \multicolumn{3}{c}{ GSTP1 } & \multicolumn{2}{c}{ GSTT1 } & \multicolumn{2}{c|}{ GSTK1 } & \multicolumn{2}{c|}{ GSTO1 } \\
\cline { 2 - 10 } & Total $(\mathbf{n})$ & Tumor $(\mathbf{n})$ & $\%$ & Tumor $(\mathbf{n})$ & $\%$ & Tumor $(\mathbf{n})$ & $\%$ & Tumor $(\mathbf{n})$ & $\%$ \\
\hline Gastric Cancer & 40 & 18 & 45 & 21 & 52.5 & 27 & 67.6 & 20 & 50.0 \\
\hline
\end{tabular}

When tumor and normal tissues were matched and the protein expression levels were assessed, CYP1B1 expression was stronger in tumor epithelium than normal epithelium in 24 samples. However, CYP1A1 and CYP2E1 expressions were not significantly higher in tumor epithelium than those in normal epithelium in human gastric adenocarcinoma (11 and 10 patients, respectively) (Table 2).

Among the studied proteins, GSTP1, GSTK1, GSTO1 and GSTT1 expressions were found in most of the tumor tissue samples of patients. GSTP1 expression was found in 18, GSTK1 expression was found in 27, GSTO1 expression was found in 20 and GSTT1 expression was found in 21 out of 40 patients' tumor tissues (Table 3 ).

Protein expressions of CYP1B1 was significantly higher in tumors than their surrounding normal tissue $(\mathrm{p}<0.05)$ (Table 2). As shown in Table 3, tumor tissues had significantly higher GSTT1, GSTO1 and GSTK1 expressions when compared to normal tissue $(\mathrm{p}<0.05)$.

The stronger GSTK1 staining was observed in tumor epithelium than normal epithelium in human gastric adenocarcinoma. The 27 patients was considered to have GSTK1 expression more than normal gastric tissue. GSTT1, GSTO1 and GSTP1 expressions were stronger in tumor epithelium than those in normal epithelium in gastric adenocarcinomas (21, 20, 18 patients, respectively) (Table 3).

The cells were stained with CYP1A1, CYP1B1, CYP2E1, GSTP1, GSTT1, GSTO1 and GSTK1 antibodies and their positivity in tumors and normal gastric tissues were determined. Figure 1 shows strong nuclear and cytoplasmic staining with CYP1A1 was observed in gastric adenocarcinoma cells.

In Table 4, protein expressions of CYP isoenzymes in tumor and normal tissues of gastric adenocar-

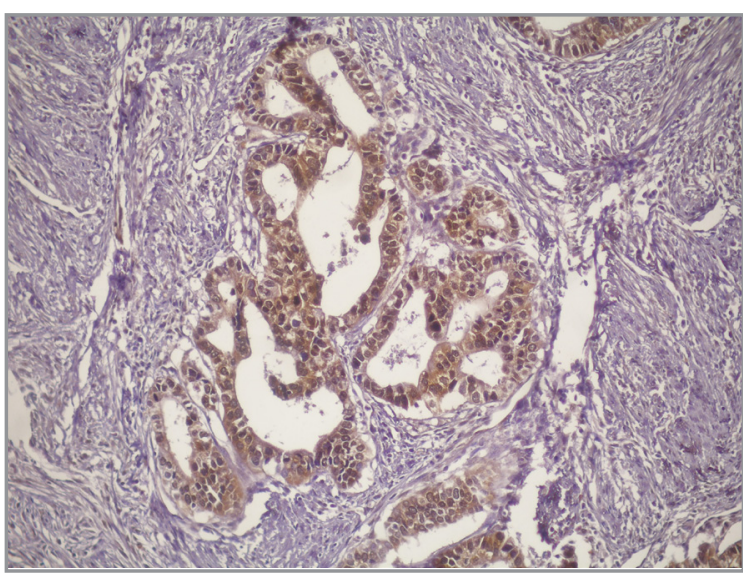

Figure 1. Immunohistochemical expression of CYP1A1 isoenzyme in patients with gastric adenocarcinoma. X200.

cinoma patients and their statistical differences are given. When protein expression differences between tumor and normal tissues of gastric adenocarcinoma patients were examined according to the averages of immunohistochemical scoring; it was seen that protein expressions of CYP1A1, CYP1B1 and CYP2E1 isoenzymes were higher in tumor tissues in comparison to normal tissues. In the conducted statistical analysis, higher protein expression of CYP1B1 isoenzyme in tumor tissues in comparison to normal tissues was found to be statistically significant $(\mathrm{p}<0.05)$; protein expression differences of CYP1A1 and CYP2E1 isoenzymes could not be verified statistically ( $>0.05$ ) (Table 4). When the average immunohistochemical scorings of well, moderately and poorly differentiated gastric adenocarcinoma patients were examined based on tumor grades; it was found that protein expressions of CYP1A1, CYP1B1 and CYP2E1 isoenzymes were higher in tumor tissues in comparison to normal tissues, but whereas higher protein expression of CYP1B1 isoenzyme in tumor tissues in comparison to normal tissues was found to be statistically significant $(p<0.05)$ 


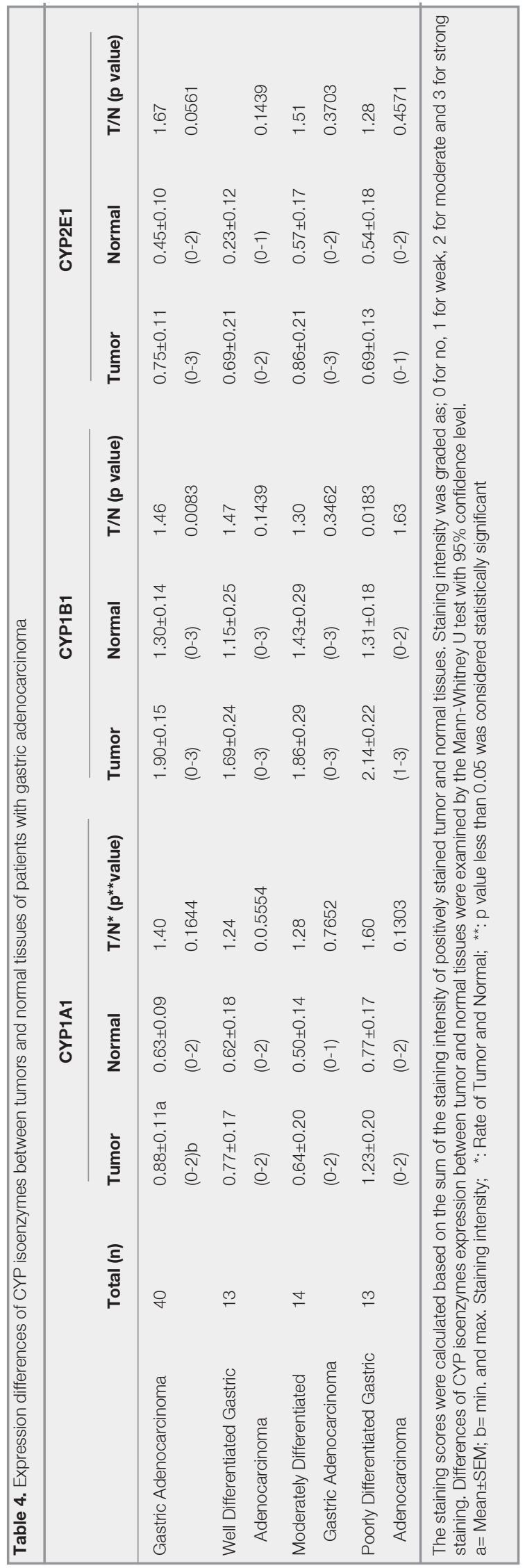

in poorly gastric adenocarcinoma patients, protein expression differences of CYP1A1 and CYP2E1 isoenzymes could not be verified statistically ( $\mathrm{p}>$ 0.05 ) in other tumor grades (Table 4).

In Table 5, protein expressions of GST isoenzymes in tumor and normal tissues of gastric adenocarcinoma patients and their statistical differences are given. When protein expression differences between tumor and normal tissues of gastric adenocarcinoma patients were examined according to the averages of immunohistochemical scoring; it was seen that protein expressions of GSTP1, GSTT1 and GSTA1 isoenzymes were higher in tumor tissues in comparison to normal tissues. In the conducted statistical analysis, higher protein expression of GSTP1 and GSTT1 isoenzyme in tumor tissues in comparison to normal tissues was found to be statistically significant $(\mathrm{p}<0.05$; $\mathrm{p}<0.05$ respectively); however, protein expression differences of GSTA1 isoenzyme could not be verified statistically $(\mathrm{p}>0.05)$ (Table 5$)$. When the average immunohistochemical scorings of well, moderately and poorly differentiated gastric adenocarcinoma samples from patients were examined based on tumor grades; it was found that protein expressions of GSTP1, GSTT1 and GSTA1 isoenzymes were higher in tumor tissues in comparison to normal tissues, but higher protein expression of GSTT1 isoenzyme in tumor tissues in comparison to normal tissues was only found to be statistically significant $(\mathrm{p}<0.05)$ in well differentiated gastric adenocarcinoma patients, in other tumor grades protein expression differences of GSTP1 and GSTA1 isoenzymes could not be verified statistically $(\mathrm{p}<0.05)$ in other tumor grades (Table 5). Figure 2 shows that moderate nuclear and cytoplasmic staining with GSK1 was observed in gastric adenocarcinoma cells.

There was no statistically significant relationship between the clinical data of the patients such as gender, age, tumor grades and the expressions of CYP and GST isoenzymes in tumor and normal tissues of patients $(\mathrm{p}>0.05)$.

\section{DISCUSSION}

Glutathione S-transferases are the most important class of enzymes involved in the protection of cells 


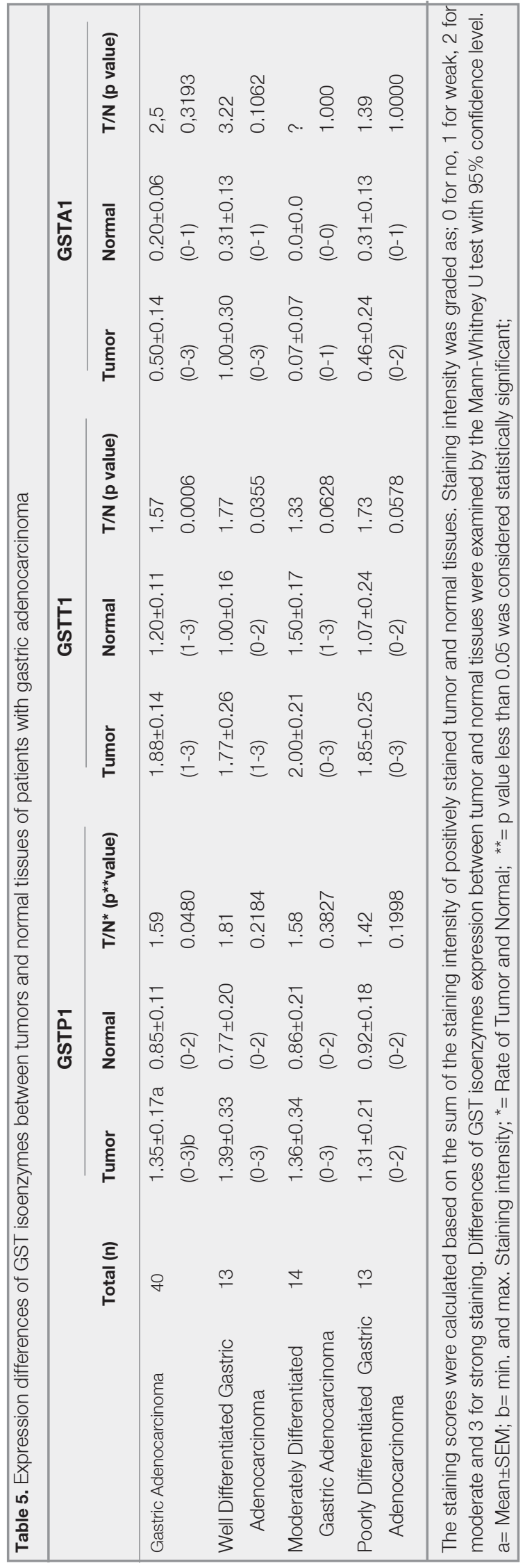

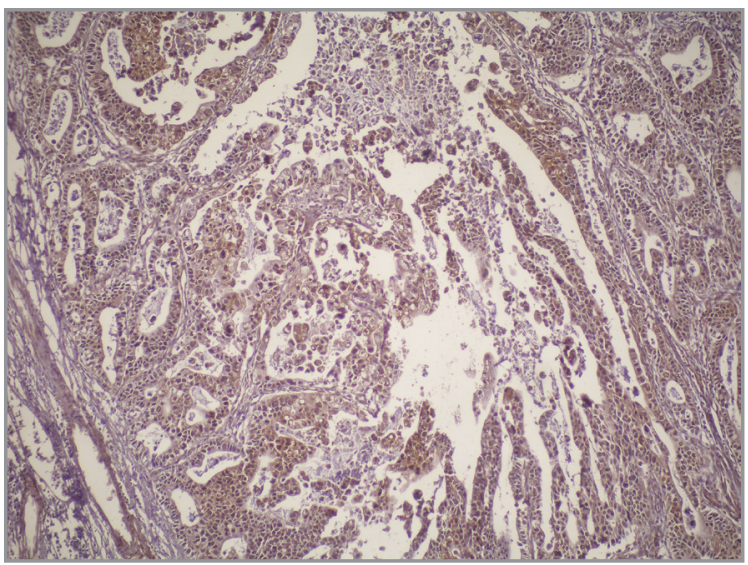

Figure 2. Immunohistochemical expression of GSTK1 isoenzyme in patients with gastric adenocarcinoma X100.

from the toxic effects of reactive electrophiles. Both increased and reduced levels of expression of specific GST isoenzymes in tumors, particularly in those that have become resistant to anti-cancer drugs, suggest a role for these proteins in the development of resistance to chemotherapy. Determination of the GST isoenzyme profile of a cancer tissue could have prognostic value in the selection of treatment. ${ }^{13}$

To our knowledge, this study represents the first comprehensive description of tissue specific expression differences of CYPs and GSTs together between gastric tumor tissue and normal gastric tissue in the same patients. Cancer cells exhibit multiple alterations that result in functional and morphological differences from normal cells. Because tumor cells are known to change some of their functions especially overexpression of proteins during the malignant transformation process, it can be suggested that higher expression levels of CYPs and GSTs in the tumor cells might be a result of this transformation.

GSTs are an important family of enzymes involved in detoxification of several xenobiotics, so this mechanism protects tissues from the harmful effects of oxidative stress, and therefore against chemically induced tissue damage. We found that CYP1B1, GSTT1, GSTO1 and GSTK1 expressions were stronger in gastric adenocarcinoma than normal tissue $(\mathrm{p}<0.05)$. High tissue levels of glutathione S-transferases (GSTs), a family of de- 
toxification enzymes, are inversely correlated with cancer risk in the human gastrointestinal tract. ${ }^{11}$

An immunohistochemical study ${ }^{13}$ of GST in breast cancer reported in normal epithelium there was a stronger intensity of staining for GST alpha, mu, and pi expression than in invasive tumor tissues $(\mathrm{p}<0.05)$. Oguztuzun $\mathrm{S}$, et al. ${ }^{14}$ investigated the immunohistochemical staining characteristics of glutathione-S-transferase alpha, pi, mu, theta and p53 in non-small cell lung carcinoma and normal lung tissue from 50 patients. They found that glutathione-S-transferase alpha, pi, mu, theta expressions in tumor cells were significantly higher than normal cells $(\mathrm{p}<0.05)$. Oguztuzun $\mathrm{S}$, et al. ${ }^{15}$ using immunohistochemistry, detected that the urothelial cancer cells had stronger staining intensity than the benign cells had in $48 \%$ of cases for GSTA, $46 \%$ of cases for GSTP, $38 \%$ of cases for GSTM4, and $42 \%$ of cases for GSTT1 from 124 bladder carcinoma patients. Simsek G, et al. ${ }^{16}$ investigated the immunohistochemical staining characteristics of glutathione-S-transferase (GST) alpha, pi, mu, and theta in prostatic acinar adenocarcinoma (PCA), prostatic intraepithelial neoplasia (PIN), and benign prostatic tissues from 19 patients. They found that GST alpha, pi, mu, and theta expressions in tumor cells were significantly lower than in PIN and benign epithelial cells $(\mathrm{p}<0.05)$. The downregulation of GST isoenzymes in PCA of the prostate and shows that the loss of GST isoenzyme expression is a phenotype associated with malignant transformation.

La Torre et al. reported the results of a meta-analysis concerning GSTM1 polymorphism and risk of gastric cancer. ${ }^{17}$ As GSTT1 is expressed at relatively high levels in many cell types of the human gastrointestinal tract. ${ }^{18,19}$ Several case-control studies had null genotypes of GSTM1 and GSTT1 had an increased gastric cancer risk compared with those who had both active genes. ${ }^{20}$ Based on a recently published meta-analysis study, there is a significant association between GSTM1 polymorphism and risk of gastric cancer. ${ }^{21}$ Many studies reported the combination genotypes of GSTM1 and GSTT1 in control subjects and gastric cancer patients increased the risk of gastric cancer. ${ }^{22-27}$

Yoshinori et al. showed that patients who were heavy smokers with the genotypes $\mathrm{Val} / \mathrm{Val}(\mathrm{V} / \mathrm{V})$ for CYPIAI and the combined genotype of V/V for CYP1A1 and GSTM10 were a statistically high risk group for esophageal carcinoma, compared with control subjects. ${ }^{28}$

Two previous studies (Kumarakulasingham et al., de Waziers et al. ${ }^{29,30}$ which have analyzed the CY$\mathrm{P} 1 \mathrm{~A} 1$ protein expression in human colon failed to detect significant differences of CYP1A1 protein level between tumor mucosa samples and normal colon mucosa samples. In our study, CYP1B1 expression was stronger in tumor epithelium than normal epithelium in the majority of the samples.

Gibson and coworkers ${ }^{31}$ detected higher CYP1B1 expression in colon adenocarcioma tissue than adjacent normal mucosa by immunohistochemistry. Murray and coworkers ${ }^{32}$ found high CYP1B1 expression in colon cancer but they did not detect CYP1B1 in normal colon. Kumarakulasingham et al. ${ }^{29}$ and Chang et al. ${ }^{33}$ found that immunohistochemical staining of CYP1B1 showed greater intensity of expression in colorectal carcinoma patients compared to normal colorectal samples of healthy individuals. Based on these observations, higher expression of CYP1B1 in gastric adenocarcinoma appears to be a consistent finding.

Bergheim and coworkers ${ }^{34}$ detected the CYP2E1 protein in colonic adenoma tissues by using Western blot. They observed no difference between the mean protein levels of CYP2E1 in normal and neoplastic tissues of patients with adenoma. However, we have found a significant difference in the CYP2E1 expression between normal and gastric adenocarcinoma tissue of patients by immunohistochemistry.

In this study, although there were expressional differences between the tumor and normal tissues, there was no statistically significant correlation between the expressions of CYP and GST, and age, gender and tumor differentiation of the patients. This result may show that the expression differences of these isoenzymes between tumor and normal tissues do not depend on variables such as age, gender of patients. Despite the presence of expression differences in tumor and normal tissues, there is no significant relationship between the expression of isoenzymes and tumor differentiation. 
The number of gastric adenocancer patients in the present study was small. Future studies with substantially larger numbers of gastric cancer patients will be needed to prospectively examine the possible relationship between CYP and GST expression and prognostic factors.

To our knowledge, the present study represents the first comprehensive description of the three classes of CYPs and four classes of GSTs in gastric adenocancer tissues. As a conclusion, these results suggest that the GST, CYP population, owing to higher expression of multiple GSTs, CYPs especially CYP1B1, GSTO1, GSTT1, and GSTK1, can play a role in tumor growth and carcinogenesis of the gastric adenocancer.

This study demonstrates the wide variability in CYP and GST proteins expression in gastric adenocancer. Incorporating such an approach in larger trials may help elucidate the roles of these proteins in carcinogenesis and identify potential targets for chemoprevention.

\section{REFERENCES}

1. Correa P. Human gastric carcinogenesis: a multistep and multifactorial process: First Cancer Society Award Lecture on Cancer Epidemiology and Prevention. Cancer Res 52: 67356740, 1992.

2. Gonzalez CA, Sala N, Capella G. Genetic susceptibility and gastric cancer risk. Int J Cancer 100: 249-260, 2002.

3. Xue FB, Xu YY, Wan $Y$ et al. Association of $H$. pylori infection with gastric carcinoma. A meta-analysis. World J Gastroenterol 7: 801-814, 2001.

4. Hansson LE, Baron J, Nyren O, et al. Tobacco, alcohol and the risk of gastric cancer. A population-based case-control study in Sweden. Int J Cancer 57: 26-31, 1994.

5. Tredaniel J, Boffetta P, Buiatti E, et al. Tobacco smoking and gastric cancer: review and meta-analysis. Int J Cancer 72: 565-573, 1997.

6. Lee BM, Jang JJ, Kim HS. Benzo[ $\alpha]$ pyrenediol-expoxide-IDNA andoxidative DNA adductsassociatedwithgastricadenocarcinoma. CancerLett 125: 61-68, 1998.

7. Zhang X, Wang F, Kie T. Detection of carcinogen in source drinking water in gastric cancer prevalent areas of Zanhuang country. ChungHuaYuFang I HsuehTsaChih 29: 149-152, 1995.

8. Hayes JD, Pulford DJ. The glutathione S-transferase super gene family: regulation of GST and the contribution of the isoenzymes to cancer chemoprotection and drug resistance. Crit Rev Biochem Mol Biol 30: 445-600, 1995.
9. Strange RC, Spiteri MA, Ramachandran $S$ et al. Glutathione S-transferase family of enzymes. Mutat Res 482: 21-26, 2001.

10. Hayes JD,Flanagan JU, Jowsey IR. Glutathione Transferases, Annu Rev Pharmacol Toxicol 45: 51-88, 2005.

11. Chen SY, Liu TY, Shun CT et al. Modification effects of GSTM1, GSTT1 and CYP2E1 polymorphisms on associations between raw salted food and incomplete intestinal metaplasia in a high-risk area of gastric cancer. Int $\mathrm{J}$ Cancer 108: 606-612, 2004.

12. García-González M A, Quintero E, Bujanda L et al. Relevance of GSTM1, GSTT1, and GSTP1 gene polymorphisms to gastric cancer susceptibility and phenotype. Mutagenesis 27: $771-77,2012$

13. Oguztuzun S, Iscan M, Özhavzali M, Dizbay Sak S. Comparison of GST isoenzyme expression in normal and neoplastic breast tissue: correlation with clinical and prognostic factors. Turk J Biol 33: 89-100, 2009.

14. Oguztuzun S, Sezgin Y, Yazici S, Firat P, Özhavzali M, Özen $H$. Expression of glutathione $S$ transferases isoenzymes and p53 in exfoliated human bladder cancer cells. Urol Oncol 29: 538-544, 2011.

15. Oguztuzun S, Aydin M, Demirag F, et al. The expression of GST isoenzymes and p53 in non-small cell lung cancer. Folia Histochem Cytobiol 48: 122-27, 2010.

16. Simsek G, Oguztuzun S, Guresci S, et al. The expression of GST isoenzymes in acinar adenocarcinoma, intraepithelial neoplasia, and benign prostate tissue: correlation of clinical parameters with GST isoenzymes. Turk J Biol 36, 687-693, 2012.

17. La Torre G, Boccia S, Ricciardi G. Glutathione S-transferase M1 status and gastric cancer risk: a meta-analysis. CancerLett 217: 53-60, 2005.

18. deBruin WC, Wangenmans MJ, Peters WH. Expression of glutathione S-transferase alpha, $\mathrm{P} 1-1$, and $\mathrm{T} 1-1$ in the human gastrointestinal tract. Jpn J Cancer Res 91: 310-316, 2000.

19. deBruin WC, Wangenmans MJ, Board PG et al. Expression of glutathione S-transferase theta class isoenzymes in human colorectal and gastric cancers. Carcinogenesis 20: 14531457, 1999

20. Setiawan WW, Zhang ZF, Yu GP et al. GSTT1 andGSTM1 null genotypes and the risk of gastric cancer: a case-control study in a Chinese population. Cancer Epidemiol Biomark Prev 9: 73-80, 2000.

21. Saadat I, Saadat M. Glutathione S-transferase M1 and T1 null genotypes and the risk of gastric and colorectal cancers. CancerLett 169: 21-26, 2001.

22. Cai L, Yu SZ, Zhang ZF. Glutathione S-transferases M1, T1 genotypes and the risk of gastric cancer: a case-control study. World J Gastroenterol 7: 506-509, 2001. 
23. Lan $\mathrm{Q}$, Chow $\mathrm{WH}$, Lissowska J et al. Glutathione S-transferase genotypes and gastric cancer in a population-based case-control study in Warsaw, Poland. Pharmacogenetics 11: 655-661, 2001.

24. Saadat, Mostafa. Genetic polymorphisms of glutathione Stransferase T1 (GSTT1) and susceptibility to gastric cancer: a meta-analysis. Cancer science 97: 505-509, 2006.

25. Saadat M, Saadat I, Saboori Z et al. Combination of CC16, GSTM1, andGSTT1 genetic polymorphisms is associated with asthma. J Allergy Clin Immunol 113: 996-998, 2004.

26. Palli D, Saieva C, Gemma S et al. GSTT1 and GSTM1 gene polymorphisms and gastric cancer in a high-risk Italian population. Int J Cancer 115: 284-289, 2005.

27. Doney AS, Lee S, Leese GP et al. Increased cardiovascular morbidity and mortality in type 2 diabetes is associated with the glutathione S-transferase theta-null genotype: a GoDARTS study. Circulation 111: 2927-2934, 2005.

28. Yoshinori Nimura, et al. Genotyping of the CYP1A1 and GSTM1 genes in esophageal carcinoma patients with special reference to smoking. Cancer 80: 852-857, 1997.

29. Kumarakulasingham M, Rooney PH, Dundas SR, Telfer C, Melvin WT, Curran S, and Murray Gl. Cytochrome P450 Profile of Colorectal Cancer: Identification of Markers of Prognosis. Clin Cancer Res 11: 3758-3765, 2005.

30. de Waziers I, Cugnenc PH, Berger A, Leroux J-P, Beaune $\mathrm{PH}$. Drug-metabolizing enzyme expression in human normal, peritumoral and tumoral colorectal tissue samples. Carcinogenesis 12: 905-9, 1991.
31. Gibson P, Gill JH, Khan PA, Seargent JM. Cytochrome P450 1B1 (CYP1B1) Is Overexpressed in Human Colon Adenocarcinomas Relative to Normal Colon: Implications for Drug Development 1. Mol Cancer Ther 2: 527, 2003.

32. Murray, M. Altered CYP expression and function in response to dietary factors: potential roles in disease pathogenesis. Current Drug Metabolism 7: 67-81, 2006.

33. Bergheim I, Bode C, and Parlesak A. Decreased expression of cytochrome P450 protein in non-malignant colonic tissue of patients with colonic adenoma. BMC Gastroenterology 5: 34, 2005.

34. Chang H, Su JM, Huang CC, et al. Using a combination of cytochrome P450 1B1 and b-catenin for early diagnosis and prevention of colorectal cancer. Cancer Detection and Prevention 29: 562-569, 2005.

\section{Correspondence:}

Dr. Gülcin GÜLER ŞIMŞEK

Saglik Bilimleri Üniversitesi

Keçiören Saglik Uygulama Arastirma Merkezi

Tibbi Patoloji Klinigi

Keçiören, ANKARA / TURKEY

Tel: (+90-505) 4032357

Fax: (+90-312) 3569012

e-mail: drgulcinguler@gmail.com 